\title{
Production, Handling, Traditional Processing Practices and Quality of Milk in Kembata Tembaro Zone Milk Shed Area, Southern Ethiopia
}

\author{
Deginet Hailemeskel \\ Department of Animal Sciences, Faculty Agricultural Sciences, Wachemo University, Hossana, Ethiopia \\ Email address: \\ degu.ab2020@gmail.com \\ To cite this article: \\ Deginet Hailemeskel. Production, Handling, Traditional Processing Practices and Quality of Milk in Kembata Tembaro Zone Milk Shed \\ Area, Southern Ethiopia. International Journal of Animal Science and Technology. Vol. 4, No. 2, 2020, pp. 33-49. \\ doi: $10.11648 /$ j.ijast.20200402.13
}

Received: March 12, 2020; Accepted: April 16, 2020; Published: June 28, 2020

\begin{abstract}
The study was conducted in Kembata Tembaro zone, kdida Gamela and kachabira woredas, of the southern Regional State with the objectives of: to assess the milk production systems, traditional milk handling and processing practices and determine the compositional and microbiological quality of milk produced at smallholder farmers' level. A single-visit-multiple-subject formal survey was used to collect data. A total of 150 households ( 75 from each woreda) were individually interviewed. All respondents reported that they wash hands and milk vessels before milking cows. However, the overall milking hygienic practice followed by the farmers in the area is poor. Ensira is the major container used for milking and storing dairy products in the study area. All the respondents (100\%) in Kedida and 93.3 percent in kachebirra use Ensira for milking. With regard to churning, the majority of the respondents (98.7\%) in Kedida use Ensira churn while 76.32 percent in Kachebirra use clay pot churn. Terminalia brownie and Acacia spp. are the most frequently used plant species for smoking milk vessels in the study area. The major constraints to milk production in the study area lack of milk collection centers/ lack of market, and poor quality milk products to be the major problems of the traditional milk processing practices. Only two dairy cooperatives were identified in kedida woreda; whereas there is no dairy cooperative in Kachebra woreda. lack of cooling facilities coupled with lack of electric power supply are the major constraints encountered at the dairy cooperatives. The overall mean fat, protein, total solids, ash and solids-not-fat (SNF) contents of local cows' milk produced in the study area were $4.71,3.25,13.47,0.73$ and 8.78 percent, respectively. Whereas, the overall mean fat, protein, total solids, ash and SNF contents of crossbred cows' milk were 4.14, 3.45, 13.15, 0.70 and 8.96 percent, respectively. The overall mean total bacterial count, coliform count and percent lactic acid of milk produced in the study area were $7.58 \pm 0.09 \log 10 \mathrm{cfu} / \mathrm{ml}, 4.49 \pm 0.11 \log 10 \mathrm{cfu} / \mathrm{ml}$ and $0.23 \% \pm 0.01$, respectively. The overall mean of the predicted probabilities of clot-on-boiling and alcohol tests were $0.23 \pm 0.12$ and $0.51 \pm 0.11$, respectively. the microbiological quality of milk produced by individual farmers and by the dairy cooperatives in the study area was poor and this call for scrupulous hygienic measures during production and handling of milk and milk products in the study area.
\end{abstract}

Keywords: Kembata Tembro, Milk Processing, Handling, Quality

\section{Introduction}

Ethiopia possesses about 38.75 million heads of cattle [1]. Despite the high cattle resource and prevailing favorable conditions and resources, current production is low which is indicated in the low per capita milk production and increasing trend in import of milk and dairy products [2].

Milk plays a very important role in feeding the rural and urban population of Ethiopia. Milk is produced daily, sold for cash or readily processed. It is a cash crop in the milkshed areas that enables families to buy other foodstuffs and is significantly contributing to the household food security [3]. Nevertheless, milk produced by smallholders is either sold and/or consumed as fresh or soured milk or manufactured into products such as butter, ghee and cottage cheese [4]. The market is not always within easy reach for 
delivering fresh raw milk and local processors, if any exist, are constrained to make milk in excess of processing due to problems of transport [5]. Sour milk is the most common product used for processing and milk is usually soured before any further processing. Though there are a few milk processing plants in Ethiopia, much of the milk produced by rural smallholders is processed on-farm using traditional technologies [6].

Post-harvest loss of milk and milk product in Ethiopia is estimated to be in the range of $20-35$ percent of the total milk produced [7]. Most losses are associated with poor handling, contamination, the level of technology applied in the conservation of milk to extend its shelf life and lack of market. Losses occur along the whole milk chain and are most serious at farm level, with smallholder farm families incurring the highest losses.

Where potential sources of contamination occur at farm level, care in milk handling during milking and subsequent storage is the first and most important step in clean milk production. However, in Ethiopia and most of sub-Saharan countries the climate is hot and humid for most of the year. Under such conditions raw milk spoils easily during storage unless it is cooled or when possible treated with a preservative. But preservatives are not readily available in rural areas, while cooling systems are not feasible in some areas because of lack of [8]. In addition, the quality of the products is usually inferior, resulting in a comparatively short shelf life and a lower price for the milk [9]. If the hygienic standards of production and handling are poor, the keeping quality of milk will be very poor due to the high ambient temperature and there will be a very high risk of spoilage [10]. Consequently, the compositional and microbial qualities of tropical milk products may differ from similar products manufactured in cooler climates [11].

The mainstay of the population in the South region being rain-fed subsistence agriculture, about 73 percent of smallholders practice mixed farming, 19 percent practice crop farming, while the remaining 8 percent undertake livestock rearing only [12]. Like other parts of the region, milk production is an integral part of the farming system in Zone. Local milk production is mainly from indigenous cattle breeds, which are kept by about half a million smallholder farming households most of them are poor. Over 99 percent of the approximately 1.3 million head of cattle in the zone are indigenous breeds. Average milk production per cow in the Zone is about 1 liter per day, resulting in an estimated milk production of 46,710,335 liters per lactation for all lactating cows. The area has potential for production of milk and milk products.

Even if the area has potential for production of milk and milk products, little is known about the existing dairy production, processing methods and marketing conditions, constraints and opportunities. In order to design relevant research that suit to the area, it is essential that researchers understand the existing situations. For the research to be effective and to meet the need of the farmers, identification of problems and understanding of the existing dairy production, processing and marketing conditions in the area is vital to devise appropriate development interventions. Furthermore, investigation regarding the feasibility of the emerging dairy cooperatives and identifying the problems and opportunities for the success of these cooperatives is an important area of study that need due attention. So far, no such study was conducted in the southern region in general and in Kembata Tembaro milk shed area in particular.

Therefore, the objectives of this study were:

1. To assess the milk production systems in Kembata Tembaro milk shed area

2. To assess the traditional milk handling and processing practices in the study area

3. To determine the compositional and microbiological quality of milk at smallholder farmers level

\section{Materials and Methods}

\subsection{Description of the Study Area}

The study was conducted in Kembata Tembaro zone Kedida Gamela and Kachebra woreda which is found at about $410 \mathrm{kms}$ south east of Addis Ababa. The elevation of the woreda $1790-3000$ m.a.s. the study area received mean annual rainfall $1100 \mathrm{~mm}$ With the minimum and maximum being 800 and $1400 \mathrm{~mm}$ respectively. The rainfall of the area is bimodal with short rain season and the long (main) rain season occurring in spring (September, October and Number) and summer (June, July and August) respectively. The mean minimum and maximum temperature are 15 and $26^{\circ} \mathrm{C}$ respectively.

\subsection{Sampling Procedures}

Before commencing the actual study, preliminary survey was conducted to gather information and data relevant for this study. Both secondary and primary data sources were used. Primary data sources were the household heads and dairy cooperatives in the respective woredas. The secondary data sources were taken from the respective woreda agricultural office, zonal office of agriculture and NGO's of the respective woredas and documents that have been written about the study area.

The target sampling population was defined as all households in the study area who currently owned both local and crossbred cows and produce milk and other dairy products. A total of 10 rural kebeles were selected; 5 RKs each from both woredas and the RKs were randomly selected. From each RK, 15 households who owned indigenous and crossbred lactating cows and produce milk were selected purposively and randomly and interviewed. Accordingly, 75 households from kedida and 75 households from Kachebra woreda and a total of 150 households from both woredas were individually interviewed using a semistructured questionnaire. The households were selected from a list of farmers registered as members of the rural kebele in 
their respective area.

\subsection{Data Collection}

The study comprised two parts: part one was a survey work conducted among farmers and dairy cooperatives, while part two was determination of the compositional and microbiological qualities of milk samples produced in the area. For the field survey, the method of data collection used was single- visit-multiple-subject survey.

\subsubsection{Survey}

Information was collected using semi-structured questionnaire by the researcher and three persons form woreda development Agent. The main theme of the survey were identification of constraints of dairy cooperatives, cattle type and number, age and sex of animals, cattle feeding and management, reproduction, milk production, handling of milk and milk products, milk storing equipment, milking practices, traditional milk processing practices and traditional dairy products, consumption of milk and milk products, marketing of milk and milk products, and major constraints in the systems. Information was obtained from both household heads. The dairy cooperatives were visited and the chairman of the cooperative was interviewed by a separate questionnaire.

\subsubsection{Sampling of Milk}

A total of fifteen milk samples were taken from each woreda among those surveyed (altogether thirty). Milk samples were collected from households producing milk from local and crossbred cows and also from dairy cooperatives based on the result of the preliminary survey. Accordingly, 7, 6 and 2 were the sample units for local cows, crossbred cows and dairy cooperatives, respectively in kedida woreda while 8 and 7 were the sample units for local cows and crossbred cows, respectively in Kachebra woreda. There was no any functional dairy cooperative in Kachebra woreda during the study period and hence this was not considered. The sample size was limited taking into consideration the limited resources and time available. Samples of raw morning milk was taken from each household once every month over a period of three months (September, October, and November, 2011) for determination of the chemical composition and microbiological quality of the milk from each woreda following standard methods as described by Marth (1978) [14]. Pooled milk was sampled within 1-2 hours after milking from the farmer's milking containers and from bulk milk at dairy cooperatives.

After thoroughly mixing, the first milk samples were placed into different volumetric flasks of about $100 \mathrm{ml}$ capacities and the second samples were placed into different sterilized universal bottles of about $60 \mathrm{ml}$ capacities. The first sample was used for chemical composition analyses while the second sample was used for microbiological test. The milk samples were kept in an ice box and delivered for analysis. All analyses were performed within 12 hours of sampling.

\subsubsection{Chemical Composition}

Milk fat: The Gerber method was used to determine the milk fat content. Ten $\mathrm{ml}$ of sulfuric acid was dispensed into a butyrometer. Then, $11 \mathrm{ml}$ of milk and one $\mathrm{ml}$ of amyl alcohol were added into a butyrometer having the sulfuric acid. The butyrometer was then stoppered and the sample was shaken and inverted several times until all the milk was digested by the acid. Then the butyrometer was placed in a water bath at $65^{\circ} \mathrm{C}$ for five minutes. The sample was centrifuged for five minutes at $1100 \mathrm{rpm}$. Finally, the sample was returned back to the water bath and kept for 5 minutes at $65^{\circ} \mathrm{C}$ and fat percentage was read from the butyrometer scale [4]. Those samples having higher or lower percentages beyond the normal fat ranges were rejected. Finally, average of duplicate samples was computed and precession of analysis was determined at 5 percent level.

Total protein: Formaldehyde titration method was used to determine the total protein content of milk [4]. Ten $\mathrm{ml}$ of milk was added into a beaker. Then $0.4 \mathrm{ml}$ of 0.4 percent potassium oxalate and $0.5 \mathrm{ml}$ of 0.5 percent phenolphthalein indicator were added into the milk. It was allowed to stand for two minutes and then the mixture was titrated with N/9 sodium hydroxide solution until pink colour was obtained. At this stage, two $\mathrm{ml}$ of neutral 40 percent formalin (the formalin solution was made neutral by adding a few drops of phenolphthalein and then adding sodium hydroxide drop by drop until a faint pink colour was obtained) was added to discharge the pink colour. The titration was continued until a pink color of equal intensity was again obtained. Finally, the number of $\mathrm{ml}$ of the $\mathrm{N} / 9 \mathrm{NaOH}$ used after the addition of formalin multiplied by 1.74 gives the percentage protein in the milk [4].

Total solids: To determine the total solids content five grams of milk sample was placed in a pre-weighed and dried duplicate crucibles. The samples were kept at $102^{\circ} \mathrm{C}$ in a hot air oven for 3 hours. The dried samples were taken out from the oven and placed in desiccators to cool and finally weighed.

$$
\text { Total solids }=\left(\frac{\text { Weight of dried sample }}{\text { Sample weight }}\right) \times 100
$$

Solids-not-fat: The solid-not-fat (SNF\%) content was determined by subtracting the percent fat from total solids [5].

Total ash: The total ash content was determined by igniting the dried milk samples in a muffle furnace in which the temperature was slowly raised to $550^{\circ} \mathrm{C}$. The sample was ignited until carbon (black color) disappears and a light gray or white ash remains [15].

$$
\text { Total ash }=\left(\frac{\text { Weight of residue }}{\text { Weight of sample }}\right) \times 100
$$

\subsubsection{Microbiological Tests}

The microbial tests considered were Standard Plate Count (SPC), Coliform Count (CC), titratable acidity, alcohol test 
and clot-on-boiling test. For determination of standard plate count and coliform count, peptone water was sterilized by autoclaving at $121^{\circ} \mathrm{C}$ for 15 minutes. Similarly the total plate count agar (Oxoid) used for determination of total viable organisms was sterilized by autoclaving at $121^{\circ} \mathrm{C}$ for 15 minutes, while the violet red bile agar (VRBA: Oxoid) used for determination of $\mathrm{CC}$ was sterilized by boiling [15]. For both tests, the media used were prepared according to the guidelines given by the manufacturers. Each analysis was made in duplicate precession of the analysis was determined at 5 percent level.

Standard plate count (SPC): The total bacterial count was made by adding $1 \mathrm{ml}$ of milk sample into sterile test tube having $9 \mathrm{ml}$ peptone water. After thoroughly mixing, the sample was serially diluted up to $1: 10^{-7}$ and duplicate samples $(1 \mathrm{ml})$ were pour plated using $15-20 \mathrm{ml}$ standard plate count agar solution and mixed thoroughly. The plated sample was allowed to solidify and then incubated at $30^{\circ} \mathrm{C}$ for 48 hours. Colony counts were made using colony counter [14].

Coliform count (CC): One $\mathrm{ml}$ of milk sample was added into sterile test tube having $9 \mathrm{ml}$ peptone water. After mixing, the sample was serially diluted up to $1: 10^{-5}$ and duplicate samples $(1 \mathrm{ml})$ were pour plated using $15-20 \mathrm{ml}$ Violet Red Bile Agar solution (VRBA). After thoroughly mixing, the plated sample was allowed to solidify and then incubated at $30^{\circ} \mathrm{C}$ for 24 hours. Finally, colony counts were made using colony counter [14]. Typical dark red colonies were considered as coliform colonies.

Titratable acidity test: Ten $\mathrm{ml}$ of milk was pipetted into a beaker and then 3-5 drops of 0.5 percent phenolphthalein indicator was added into the milk. Then the sample was titrated with $0.1 \mathrm{~N} \mathrm{NaOH}$ solution until definite pink colour persists [4]. Percent lactic acid was calculated as:

$$
\text { Lactic acid }(\%)=\left(\frac{m l N / 10 \text { alkali }^{\times 0.009}}{m l \text { of sample }}\right) \times 100
$$

Alcohol test: Five $\mathrm{ml}$ of milk and $5 \mathrm{ml}$ of 68 percent alcohol (ethanol) were placed in a test tube. The test tube was inverted several times with the thumb held tightly over the open end of the tube. Then the tube was examined for formation of curd particles [4].

Clot-on-boiling test: Five $\mathrm{ml}$ of milk was placed in a test tube and it was placed in a boiling water bath for five minutes. Then, the test tube was carefully removed from the water bath and examined for the presence of floccules [4].

\subsection{Statistical Analysis}

Statistical Package for Social Science (SPSS) version 12 was used to analyze the data collected through the survey. Means were separately calculated for chemical composition and bacteriological tests for locations and the farm groups (farmers and dairy cooperatives). The General Linear Model (GLM) procedure of SAS (2000) [16] for least square analysis of variance was used to analyze the laboratory results. A fixed effect model was used to estimate the effects of locations and farm groups on the chemical composition and bacteriological tests. Predicted probabilities for clot-onboiling and alcohol tests were analyzed using SPSS version 12 to estimate variances of predicted probabilities in a logit response regression. Total bacterial and coliform counts were log transformed before statistical analysis in order to make the frequency distribution more symmetrical. Mean comparisons were done using the Least Significant Difference (LSD) for variables whose F-values declared a significant difference. Differences were considered statistically significant at 5, 1, and/or $0.1 \%$ significance level.

The following model was used for analysis of milk composition and microbiological quality of milk:

$$
\mathrm{Y}_{\mathrm{ij}}=\mu+\alpha_{\mathrm{i}}+\beta_{\mathrm{j}}+\mathrm{e}_{\mathrm{ij}}
$$

Where,

$\mu$ is the overall mean,

$\mathrm{Y}_{\mathrm{ij}}$ refers to individual observation

$\alpha$ is the $i^{\text {th }}$ locations effect

$\beta$ is the $\mathrm{j}^{\text {th }}$ farm groups effect and

$\mathrm{e}_{\mathrm{ij}}$ is the error term

\section{Results and Discussion}

\subsection{Household Resources}

\section{Household Characteristics}

The household size, age group and educational status per household in the study areas are shown in Table 1 . The average family size per household in Kedida and Kachabira woredas were 8.22 and 7.2 persons, respectively with the overall mean of 7.71 persons per family in the study area.

The average household size observed in this study is smaller than that reported by Solomon (2004) who found that the overall mean household size in Bale highlands was 8.73 persons per household. However, it is larger than that reported by Getachew (2002) [17]who found an average household size of 5.6 persons per household in Ginchi highlands. The proportion of children (1- 14 years of age) in each household was 34.37 percent, while that of older people ( $>55$ years of age) in the household was 25.42 percent in the study area. The proportion of the middle age group in the area (15-55 years of age) was 40.21 percent. In this study, higher proportions of the population are in working age, which is important to undertake agricultural activities.

The educational status of the family members of the respondents in the study site is indicated in Table 1 . The proportion of illiterate family members exceeds the proportion of those who are able to read and write and attending formal education. However, the relative literacy level observed per household can provide a better opportunity to implement agricultural practices and efficient resource use in the study area. 
Table 1. Average household size, age category and educational status per household in the study area.

\begin{tabular}{|c|c|c|c|c|c|}
\hline \multirow{2}{*}{ Variables } & \multicolumn{2}{|c|}{ Kedida $(\mathrm{N}=75)$} & \multicolumn{2}{|c|}{ Kachebira $(\mathrm{N}=75)$} & \multirow{2}{*}{ Overall Mean } \\
\hline & Mean & SD & Mean & SD & \\
\hline Household size & 8.22 & & 7.2 & & 7.71 \\
\hline $1-14 \mathrm{yr}$ of age & 2.96 & 1.12 & 2.34 & 1.02 & 2.65 \\
\hline $15-55 \mathrm{yr}$ of age & 3.29 & 1.55 & 2.91 & 1.54 & 3.1 \\
\hline$>55 \mathrm{yr}$ of age & 1.97 & 1.14 & 1.95 & 1.01 & 1.96 \\
\hline \multicolumn{6}{|c|}{ Educational status of $\mathrm{HH}$} \\
\hline Illiterate & 2.32 & 1.58 & 2.50 & 1.12 & 2.41 \\
\hline $1-4$ grade & 1.53 & 0.68 & 1.13 & 0.92 & 1.33 \\
\hline 5-8 grade & 1.47 & 0.95 & 1.07 & 1.03 & 1.27 \\
\hline $9-12$ grade & 1.62 & 1.08 & 1.22 & 0.80 & 1.42 \\
\hline
\end{tabular}

$\mathrm{N}=$ number of respondents; $\mathrm{SD}=$ Standard Deviation; $\mathrm{yr}=$ years; $\mathrm{HH}=$ Household.

\subsection{Handling Practices of Milk and Milk Containers in the Study Area}

\subsubsection{Milking and Milk Handling Practices}

In the study area cows were hand milked and calves are allowed to suckle their dams prior to as well as after milking. The respondents noted that they also practice milking cows in the absence of their calves (Table 2). About 90.7 and 82.7 percent of the respondents in Kedida and Kachabira woredas, respectively reported that they milk their cows two times a day. While 9.3 and 17.3 percent of the respondents in Kedida and Kachabira woredas, respectively reported that they milk their cows only in the evening.
The majority of the respondents in the study area do not follow sanitary milking practices (Table 2). All respondents reported that they wash hands and vessels before milking cows. However, dipping of milker's fingers into the milking vessel and moistening teats of the cows to facilitate milking is practiced in the study area. This practice may allow microbial contamination of the milk from the milker's hand and thus should be discouraged. Similar practices are done in east Shoa Zone of Oromia region [18]. In the current study area, the use of towel to clean the udder of cows is very limited (Table 2).

Table 2. Milking frequency and milking procedure in the study area.

\begin{tabular}{lll}
\hline \multirow{2}{*}{ Variables } & Kedida $(\mathbf{N}=\mathbf{7 5})$ & Kachabira $(\mathbf{N}=\mathbf{7 5})$ \\
\cline { 2 - 3 } & Percent of total respondents & Percent of total respondents \\
\hline Milking frequency & & \\
Morning and evening & 90.7 & 82.7 \\
Evening only & 9.3 & 17.3 \\
Milking procedure & 100 & 100 \\
Washing hands and vessels & 24 & 12 \\
Udder washing before milking & 76 & 88 \\
Do not wash udder & & \\
Use of towel & 2.7 & 1.3 \\
Use of individual towel & 8 & 9.7 \\
Use of collective towel & 89.3 & 89 \\
No use of towel & 96 & 94.7 \\
Milking cows in case of calf death & & \\
\hline
\end{tabular}

$\mathrm{N}=$ number of respondents.

\subsubsection{Containers Used for Storage and Processing of Dairy Products}

Table 3 shows the different containers used for milking, churning and storage of various dairy products produced in the study area. Ensira is the major container used for milking and storing dairy products in the study area. The Ensira used for different purposes differ in size. The small size Ensira used for milking is called shate while the medium size Ensira used for storage is called Bosso and the larger size Ensira used for churning is called zale. Ensira and plastic containers are used for milking in the study area (Table 3). All the respondents $(100 \%)$ in Kedida and 70.09 percent in Kachabira woreda use Ensira (Bosso) for milking. Furthermore, 29.91 percent of the respondents in Kachabira woreda use plastic containers for milking.

With regard to churning, the majority of the respondents (98.7\%) in Kedida use Ensira churn while 23.68 and 76.32 percent in Kachabira woreda use Ensira and clay pot churn, respectively. The respondents especially in Kedida indicated that they prefer Ensira churn due to its efficiency and the ease to get it by growing it in the home stead. On the contrary, those respondents from Kachabira woreda indicated that they prefer clay pot churn due to the ease of churning and the higher recovery of butter from a given volume of milk.

Ensira, clay pot and plastic containers are used in different proportions for the storage of various milk products produced in both Kedida and Kachabira woredas (Table 3). In general, the use of clay pot for storage of various dairy products and its use for churning observed in the current study is in 
agreement with the results of O'Mahony and Ephraim (1985) and Zelalem and Ledin (2001b) [19]in the central highland of Ethiopia. While the use of Ensira as a churn and a storage vessel agrees with the report of Alganesh (2002) and Lemma (2004) [20].

Table 3. Containers used for processing and storage of dairy products in the study area (percentage of the respondents).

\begin{tabular}{|c|c|c|c|c|c|c|}
\hline \multirow{2}{*}{ Purpose } & \multicolumn{3}{|c|}{ Kedida $(N=75)$} & \multicolumn{3}{|c|}{ Kachabira $(N=75)$} \\
\hline & Ensira & Clay pot & Plastic containers & Ensira & Clay pot & Plastic containers \\
\hline Milking & 100 & - & - & 70.09 & - & 29.91 \\
\hline Churning & 98.7 & 1.3 & - & 23.68 & 76.32 & - \\
\hline Storage & & & & & & \\
\hline Fermented milk & 60.5 & 39.5 & - & 46.6 & 53.4 & - \\
\hline Buttermilk & 52.03 & 41.46 & 6.51 & 34.44 & 48.89 & 16.67 \\
\hline Cottage cheese & - & 84.34 & 15.66 & - & 79.78 & 20.22 \\
\hline Ghee & 66.67 & 33.33 & - & 82.35 & 17.65 & - \\
\hline Metata ayib & 50.43 & 37.61 & 11.96 & 43.82 & 17.65 & - \\
\hline Zure & - & 63.92 & 36.08 & - & 85.71 & 14.29 \\
\hline
\end{tabular}

$\mathrm{N}=$ number of respondents.

\subsubsection{Cleaning and Smoking Milk Vessels}

The plants that are used for cleaning and smoking milk vessels are indicated in Table 4. All the respondents practice washing the utensils used for processing of milk. The most common technique is washing with warm water together with plant leaves of yesetkest, nachakitele, and kessie (Ocimum hardiense) and finally rinsing with cold water. Moreover, it was noticed that the milk utensils are washed with warm water first and then with cold water when the plant species are not available around their home stead. Ocimum hardiense (kessie in Amharic) is the most common used plant species used to clean vessels used to store milk and milk products. This report is consistent with the report of Alganesh (2002) and Lemma (2004) [20]who reported similar practices in eastern Wollega and east Shoa Zones of Oromia region, respectively.

Terminalia brownie (abalo in Amharic) and Acacia spp (cheba in Amharic) are the most frequently used plant species for smoking milk vessels in the study areas (Table 4). These plants are used to impart good flavor to the milk and milk products. Besides, it is claimed that they are known to increase the shelf life of milk when used. Zewogdem and Tegi are also used for smoking the vessels used to store milk and milk products. On the contrary, Olea africana is the most frequently used plant for smoking milk containers in other parts of the country [18-20].

Table 4. Plants used for cleaning and smoking of milk utensils in the study area.

\begin{tabular}{|c|c|c|c|c|}
\hline \multirow{2}{*}{ Vernacular name (Amharic) } & \multirow{2}{*}{ Scientific name } & \multirow{2}{*}{ Purpose } & \multirow{2}{*}{$\begin{array}{l}\text { Kedida } \\
\%\end{array}$} & \multirow{2}{*}{$\begin{array}{l}\text { Kachabira } \\
\%\end{array}$} \\
\hline & & & & \\
\hline Abalo & Terminalia brownii & Smoking & 55.56 & 39.04 \\
\hline Cheba & Acacia spp & Smoking & 23.7 & 45.73 \\
\hline Zewogdem & Unidentified & Smoking & 9.63 & 4.27 \\
\hline Tegi & Unidentified & Smoking & 11.11 & 10.96 \\
\hline Yesetkest & Unidentified & Cleaning & 29.37 & 34.87 \\
\hline Nachakitele & Unidentified & Cleaning & 20.28 & 16.45 \\
\hline
\end{tabular}

$\mathrm{N}=$ number of respondents ( 75 respondents from each woreda).

\subsection{Traditional Processing of Dairy Products}

\subsubsection{Butter Making}

In the study area, butter is made by churning sour milk (Ergo) which has been collected over a few days and allowed to ferment naturally. Most of the respondents reported that during churning time they insert a wooden stick usually with three fingers like projections at one end (locally called mesbekia) into the container half filled with fermented milk. Farmers in the area use mesbekia to break the curd and to mix the fermented milk in addition to using their hands (Table 5). When sufficient amount of milk is collected, it is transferred to a churn made of Ensira (Bosso) or clay pot. Then the milk is churned until butter granules are formed. Finally, they open the churn, skim off the butter and then the butter is kneaded and washed with cold water.

Table 5. Reported methods of breaking and mixing the curd of the sour milk.

\begin{tabular}{lll}
\hline \multirow{2}{*}{ Methods of mixing } & Kedida $(\mathbf{N}=\mathbf{7 5})$ & Kachabira $(\mathbf{N}=\mathbf{7 5})$ \\
\cline { 2 - 3 } & Respondents $(\%)$ & Respondents $(\%)$ \\
\hline Mesbekia & 33.3 & 20 \\
Hand & 42.7 & 62.7 \\
No stirring & 24 & 17.3 \\
\hline
\end{tabular}

$\mathrm{N}=$ number of respondents.

The Ensira churn used in the area is hunged on a tripod (locally called mekehal) and swung to and fro. When using clay pot, the churn is placed on a mat on the floor and rocked it back and forth until milk fat is recovered in the form of butter. According to farmers' practice the breakpoint, i.e., the 
point when butter grains start to form is detected by inserting a grass stick into the churn through a vent on the neck of the churn. If there are small butter grains adhering to the surface of the grass stick, the breakpoint has reached. Furthermore, the breakpoint of butter recovery is also known through change in the sound made while churning. The use of Ensira churn observed in the current study is inline with the report of O' Mahony and Ephraim (1985) [5] while use of clay pot churn observed in the present study is similar with the report of Zelalem and Ledin (2001b) [20] in the central highlands of Ethiopia.

The average quantity of milk processed, volume of milk used to produce $1 \mathrm{~kg}$ of butter and churning interval per household are indicated in Table 6. The average volume of fermented milk churned at a time per household in the study area is 7.5 liters. According to the respondents, volume of fermented milk churned at a time depends upon the number of milking cows, the types of milking cows (i.e., local or crossbred), the amount of fresh whole milk and sour milk (Ergo) used for Zure production and the amount consumed. The fresh milk produced in the area is not subjected to any preservative and poured into the containers for natural fermentation. However, it was noticed that the farmers clean and smoke the milk containers to trigger fermentation and to impart good aroma. They put the containers in a cooler area of their house and also change the storage vessels occasionally especially during the dry seasons.

In the present study, the average volume of fresh whole milk required to produce one kilogram of butter was 18.1 liters. This result is relatively higher than that reported by Alganesh (2002) [20] who found that an average of 16.2 liters of milk are required to produce $1 \mathrm{~kg}$ of butter in eastern Wollega.

Table 6. Reported average quantity of milk processed, volume of milk used to produce $1 \mathrm{~kg}$ of butter and churning interval in the study area.

\begin{tabular}{|c|c|c|c|c|c|}
\hline \multirow{2}{*}{ Variables } & \multicolumn{2}{|c|}{ Kedida $(\mathbf{N}=75)$} & \multicolumn{2}{|c|}{ Kachabira $(\mathrm{N}=75)$} & \multirow{2}{*}{ Overall mean } \\
\hline & Mean & SD & Mean & SD & \\
\hline Volume of fermented milk churned at a time (liters) & 7.92 & 1.91 & 7.07 & 1.73 & 7.49 \\
\hline Volume of milk used to produce $1 \mathrm{~kg}$ of butter (liters) & 17.96 & 1.45 & 18.19 & 1.37 & 18.07 \\
\hline Churning interval (days) & 3.77 & 0.67 & 3.75 & 0.7 & 3.77 \\
\hline
\end{tabular}

$\mathrm{N}=$ number of respondents; $\mathrm{SD}=$ Standard Deviation.

\subsubsection{Butter Preservation}

Spices used for butter preservation in the area are shown in Table 7. Eighty nine and 82.7 percent of the respondents reported that they preserve butter using different spices to extend its shelf life in Kachabira and Kedida woredas, respectively. The method used to add spice into butter is, first the butter is immersed (mezefizefi in Amharic) with the watery residue of Zingiber officinale (Zingebile) and Allium sativum (Nechishinkurt) and allowed to stay for one or two days. Then, it is washed with water. Finally, the remaining spices are made into powder and mixed thoroughly with the butter. Butter made as such is used either for home consumption or sale. Similar practices are followed in eastern Wollega [20] and in east Shoa Zone of Oromia region [18] to preserve butter.

Table 7. Spices used for butter preservation in the study area.

\begin{tabular}{|c|c|c|c|c|}
\hline \multirow{2}{*}{ Local name (Amharic) } & \multirow{2}{*}{ Botanical name } & \multirow{2}{*}{ Scientific name } & \multirow{2}{*}{$\begin{array}{l}\text { Kedida }(N=75) \\
\%\end{array}$} & \multirow{2}{*}{$\begin{array}{l}\text { Kachabira }(\mathrm{N}=75) \\
\%\end{array}$} \\
\hline & & & & \\
\hline Zingebile & Ginger & Zingiber officinale & 82.7 & 89.3 \\
\hline Korerima & Korerima & Aframomum korarimao & 74.7 & 72 \\
\hline Nechishinkurt & Garlic & Allium sativum & 82.7 & 89.9 \\
\hline Kirinfude & Clove & Syzygium aromatium & 57.3 & 70.7 \\
\hline Zekakibe & Basil & Ocimum spp. & 53.3 & 68 \\
\hline Tenadam & Rue & Ruta graucolence & 74.7 & 64 \\
\hline Tikurabosuda & Black cumin & Nigella sativa & 44 & 74.7 \\
\hline Timze & & Unidentified & 36 & 62.7 \\
\hline Abish & Fenugreek & Trigonella foeniculum & 54.7 & 66.7 \\
\hline Irid & Turmeric & Curcuma domestica & 49.3 & 36 \\
\hline Mekimeko & & Unidentified & 28 & 41.3 \\
\hline Donot preserve & & & 17.3 & 10.7 \\
\hline
\end{tabular}

$\mathrm{N}=$ number of respondents; the respondents used more spices at a time.

\subsubsection{Ghee Making and Utilization}

Ghee is made by melting butter. It is not marketed in the study area rather it is exclusively used for home consumption. Butter is placed into a clay pot and put on open fire to melt. Heating and stirring continue until foam is formed and a clear liquid is obtained. Along heating the butter, spices are added to impart good aroma and taste. Then the pot is removed from the fire and allowed to cool. Finally, the liquid is filtered through sieve or piece of cloth into a container. Similar procedures have also been reported by many authors in Ethiopia [4, 18, 20]. Another practice noticed in the study area is that some respondents melt the butter as usual and then remove it from 
the fire and keep it overnight after adding water on top of it, believing that it clearly filters the melted butter (ghee) from the residue. After draining the residue again they put it on fire for a few minutes as usual along with spices for further removal of the residue.

Different spices are used during ghee making which varies from household to household. The different types of spices used in both woredas of the study site are shown in Table 8. It is common in the study area that ghee is used during cooking wot, eating raw meat and mixed with coffee and drunk. It is also used by some households when eating Metata Ayib.

Table 8. Spices used during ghee making in the study area.

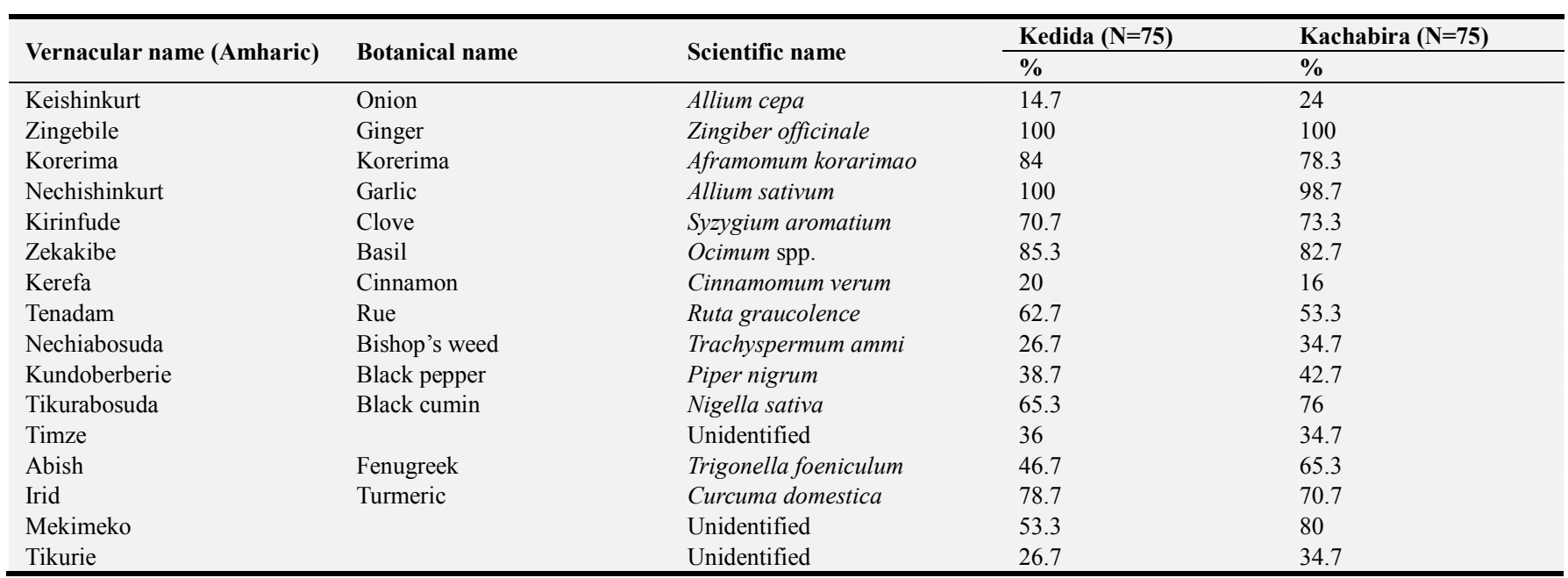

$\mathrm{N}=$ number of respondents; the respondents used more spices at a time.

\subsubsection{Cottage Type Cheese (Ayib) Making and Utilization}

All the respondents in the study area reported that they make Ayib from cows' milk. Buttermilk, which is a byproduct of the butter making process, is the raw material used for cottage cheese making. The buttermilk is placed on a clay pot and warmed on slow fire at approximately $40^{\circ} \mathrm{C}$ to $50^{\circ} \mathrm{C}$ for twenty to thirty minutes. After cooling, the whey is drained off. This procedure of Ayib making is consistent with the reports of many authors in Ethiopia [4, 18, 20, 21]. The cottage cheese made at the household level is not marketed but used for consumption, and/or Zure production. On the other hand, the whey obtained is either used for consumption by the family members or given to animals (such as cat, dog and calf). In rare cases, whey is used during Zure production to increase the amount of the product. In the current study, on the average about 8.9 liters of buttermilk is required to produce a kilogram of cottage cheese. This value is in agreement with the yield estimates for cottage cheese reported by O'Connor (1993) [4]. According to the respondents, cottage cheese can be kept unspoiled up to 3 days at ambient temperature.

\subsubsection{Zure Making and Utilization}

Zure is one of the traditional dairy products produced in the study area. The raw materials used for Zure making include whole fresh milk, buttermilk, cottage cheese, sour milk and whey. The respondents reported that Zure is made on occasional basis and mostly considered as refreshment. According to the response of the farmers, Zure is the most nutritious of the dairy products. The reason for occasional preparation of Zure is due to the use of fresh whole milk and sour milk for further processing.
In the study area, different methods of Zure making are reported and the procedures are indicated below:

Type 1. First fresh whole milk is placed on a clay pot or pan and warmed on a slow fire at approximately $30^{\circ} \mathrm{C}$ to $40^{\circ} \mathrm{C}$ for a few minutes and then buttermilk is added. If there is a need to increase the amount, whey (the byproduct obtained during cottage cheese making) is also added but not common. Immediately after adding buttermilk or whey or both on the warmed fresh whole milk, the mixture is continuously stirred with a wooden stick that has two projections at one end (locally called bala). The stirring is continued for approximately 20-30 minutes until coalesced Zure formed. After gradual cooling, Zure is taken out using ladle and the whey remains in the pot. Alternatively, the whey is poured out and Zure remains in the pot. The name Zure is given from the stirring action exercised during its production.

Type 2. Fresh whole milk is placed on a clay pot or pan and warmed on a slow fire at approximately $30^{\circ} \mathrm{C}$ to $40^{\circ} \mathrm{C}$ for a few minutes and then cottage cheese is added. The rest steps are the same as Type 1.

Type 3. Sour milk (Ergo) is placed on a clay pot or pan and warmed on a slow fire at approximately $30^{\circ} \mathrm{C}$ to $40^{\circ} \mathrm{C}$ for a few minutes. When it starts warming, it is continuously stirred with bala just like types one and two described above.

In all of the types identified, the final mixture is coalesced into a semi-solid mass called Zure and the whey is considered as a byproduct just like that of cottage cheese making but the whey obtained during Zure making is totally consumed (drunk) in the household and according to the farmers' response it is nutritious unlike the whey obtained during cottage cheese making. At the household level, Zure is 
prepared when needed on daily basis and exclusively used production needs further investigation. for home consumption. Its shelf life is one day. Thus, Zure

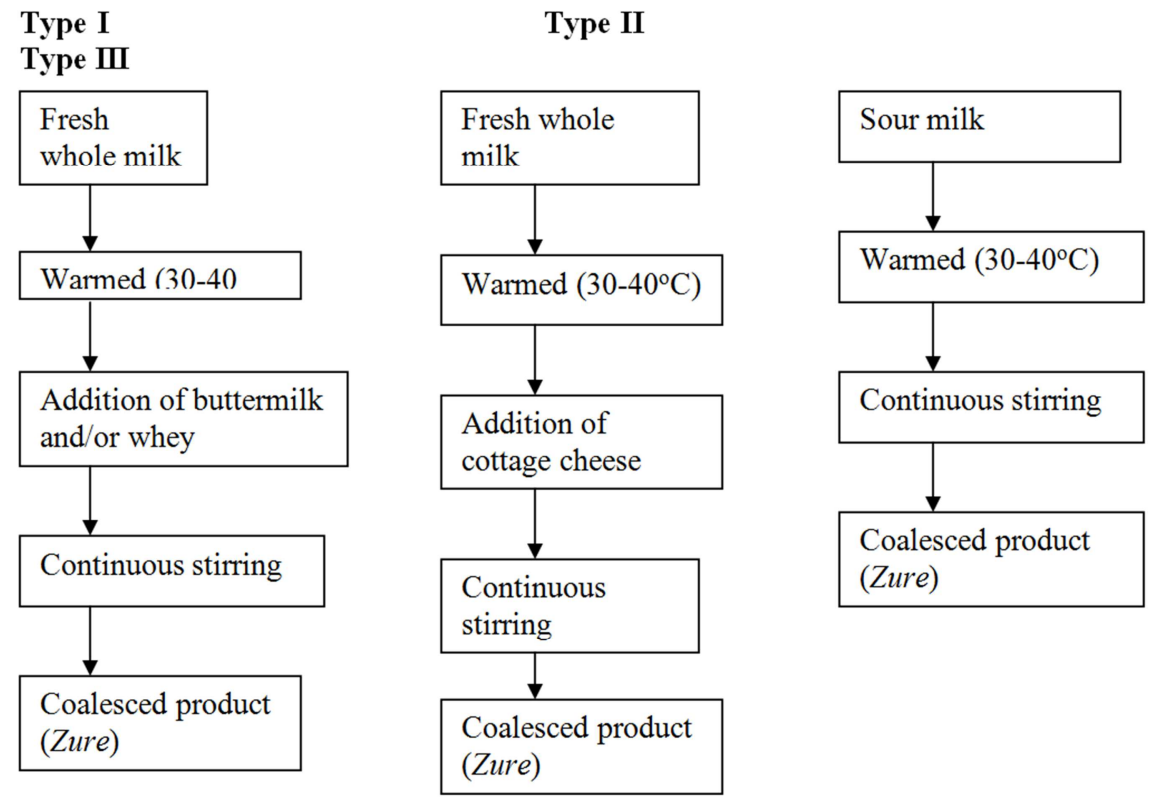

Figure 1. Flow diagram for Zure Making.

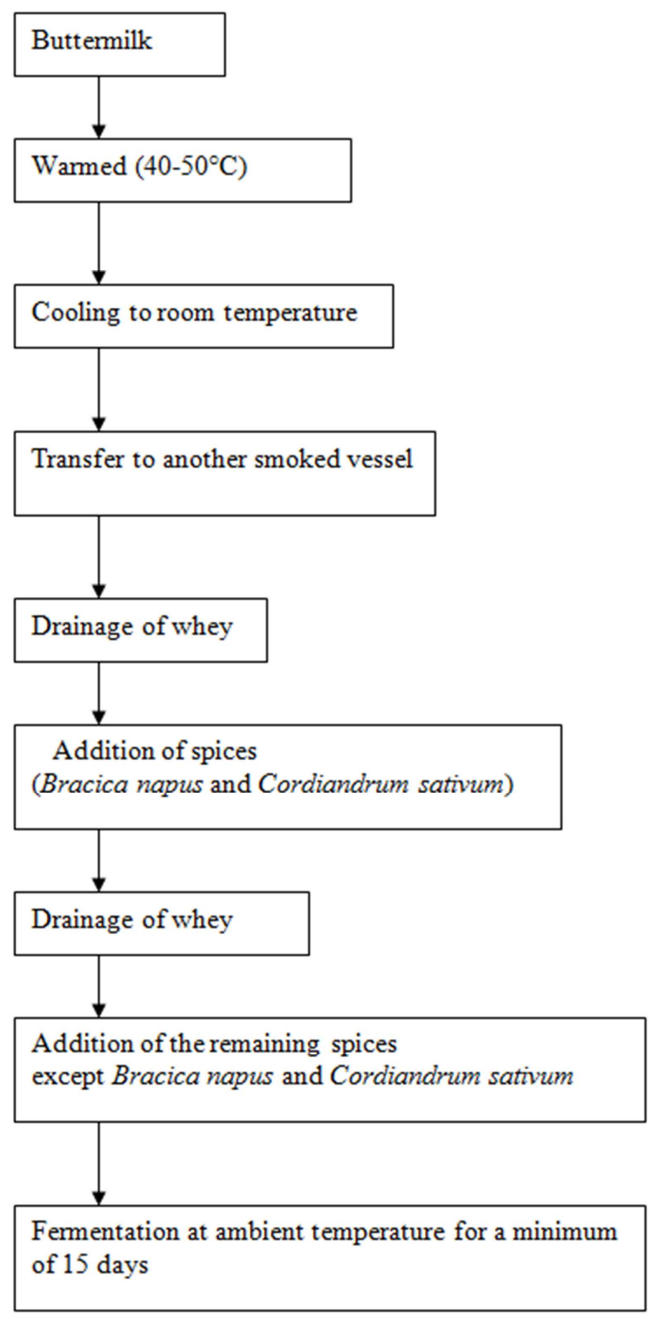

Figure 2. Flow diagram for Metata Ayib making. 


\subsubsection{Metata Ayib Making and Utilization}

In the study area, farmers produce a product called Metata Ayib from buttermilk. The buttermilk is placed on a clay pot or pan and warmed on open fire at approximately $40^{\circ} \mathrm{C}$ to $50^{\circ} \mathrm{C}$ like that of cottage cheese making till a distinct curd mass forms. The vessel is then removed from the fire and allowed to cool. Upon cooling, the curd whey mixture is transferred into another smoked Ensira or clay pot and kept at room temperature. Next day, another batch of curd mass of cottage cheese is produced following the same procedure and added into the previous batch after completely draining the whey from the earlier batch. This step is repeated for up to 3 to 4 days until sufficient amount is obtained for making Metata Ayib.

The vessel containing the curd mixture is covered with fresh succulent grass or leaves of Wanza, Kesie, false banana (Koba in Amharic). Then the vessel is tilted down for continuous drainage of whey for up to 3 days during which the cover used is changed every day. After three days of whey drainage, ground powder of the spices Bracica napus (gomenzer) and Cordiandrum sativum (dimbilale) are added into the mixture. After adding of these spices again the vessel is tilted down for further drainage of whey for up to 3 days with continuous change of the cover used each day. Then, the tilted vessel is upturned and the drained cottage cheese is taken out from the vessel using ladle so as to mix the remaining spices (all the spices shown in Table 9 except Bracica napus (gomenzer) and Cordiandrum sativum (dimbilale). After this, all the remaining spices are added in the form of powder and thoroughly mixed with the curd mixture. Finally, the curd that is mixed with the spices is put into another smoked clay pot or Ensira and the vessel is covered with clean clothes or woven materials and kept at an ambient temperature for 15 days for natural fermentation to take place. The farmers reported that the vessel is not opened before 15 days and this is the minimum time that is required for fermentation. They reported that the vessel can be opened any time after 15 days of fermentation. The final product (i.e., Metata Ayib) is now ready for home consumption and/or sale. The farmers reported that before consumption, the Metata Ayib is thoroughly mixed either with ghee, fresh whole milk or warm water depending on the availability of ghee or fresh whole milk. Salt is also added on it before consumption.

The different types of spices that are used during Metata Ayib making in the study area are shown in Table 9. All the respondents practice Metata Ayib making at any time as long as they churn milk and get buttermilk. Farmers reported that Metata Ayib is stored for up to 3 years at an ambient temperature with out any spoilage. Besides its nutritional value, Metata Ayib is used for curing of malaria and stomach upset in the area; it is also given to animals to relieve them from bloating. Thus, Metata Ayib making is appreciated in the study area as long as there is milk because this product stays for a longer period of time and milk can be preserved by converting it to Metata Ayib especially during the long Easter fasting period by followers of the Orthodox Christian faith. In general, the properties of Metata Ayib need further and detailed scientific investigation.

\subsection{Shelf Life of Dairy Products Produced in the Study Area}

Table 10 shows the shelf life of various milk products produced in the study area. The shelf life of sour milk, cottage cheese and Metata Ayib were found to be 4.1 days, 2.9 days, and 2.8 years, respectively at an ambient temperature in the study area. The same respondents reported an average shelf life of 13.7 days for butter, 11.4 months for spiced butter and 19.2 months (1.6 years) for ghee at an ambient temperature.

The average shelf life of ghee reported in the present study is lower than that reported by Flavey and Chantalakhana (1999) [21] who found that ghee produced in Borana plateau had a shelf life of 3.5 years; however, it is higher than the value 11.6 months reported by Algnesh (2002) [20] for ghee made in eastern Wollega. In general, the shelf life of the various dairy products produced in the study area differs from the findings of other workers. This could have been due to the difference in handling practices and traditional techniques used to preserve dairy products in the study area and else where.

Table 9. Spices used during Metata Ayib making in the study area.

\begin{tabular}{|c|c|c|c|c|}
\hline \multirow{2}{*}{ Vernacular name (Amharic) } & \multirow{2}{*}{ Botanical name } & \multirow{2}{*}{ Scientific name } & \multirow{2}{*}{$\begin{array}{l}\text { Kedida }(\mathrm{N}=75) \\
\%\end{array}$} & \multirow{2}{*}{$\begin{array}{l}\text { Kachabira }(\mathrm{N}=75) \\
\%\end{array}$} \\
\hline & & & & \\
\hline Gomenzer & Mustard & Bracica napus & 100 & 100 \\
\hline Zingebile & Ginger & Zingiber officinale & 100 & 100 \\
\hline Korerima & Korerima & Aframomum korarimao & 85.3 & 77.3 \\
\hline Nechishinkurt & Garlic & Allium sativum & 100 & 100 \\
\hline Dimbilale & Cordiander & Cordiandrum sativum & 100 & 100 \\
\hline Zekakibe & Basil & Ocimum spp & 96 & 86.7 \\
\hline Tenadam & Rue & Ruta graucolence & 88 & 84 \\
\hline Nechiabosuda & Bishop's weed & Trachyspermum ammi & 28 & 36 \\
\hline Tikurabosuda & Black cumin & Nigella sativa & 92 & 93.3 \\
\hline Keishinkurt & Onion & Allium сера & 73.3 & 80 \\
\hline Abish & Fenugreek & Trigonella foeniculum & 76 & 82.7 \\
\hline
\end{tabular}

$\mathrm{N}=$ number of respondents; the respondents used more spices at a time. 
Table 10. Reported shelf life of dairy products in the study area.

\begin{tabular}{llllll}
\hline \multirow{2}{*}{ Variables } & Kedida (N=75) & & Kachabira (N=75) & Overall mean \\
\cline { 2 - 5 } & Mean & SD & Mean & SD & 4.07 \\
\hline Sour milk (days) & 4.05 & 1.08 & 4.09 & 1.09 & 13.72 \\
Butter (days) & 12.52 & 3.84 & 14.92 & 6.34 & 11.40 \\
Spiced butter (months) & 11.28 & 6.96 & 11.52 & 6.84 & 19.20 \\
Ghee (months) & 21 & 10.56 & 17.4 & 9 & 2.92 \\
Cottage cheese (days) & 2.85 & 0.98 & 2.99 & 0.63 & 2.79 \\
Metata Ayib (years) & 2.75 & 1.02 & 2.83 & 1.36 & \\
\hline
\end{tabular}

$\mathrm{N}=$ number of respondents; $\mathrm{SD}=$ Standard Deviation.

\subsection{Consumption and Utilization of Dairy Products}

Fresh whole milk, sour milk, butter, buttermilk, traditional cottage type cheese, whey, Metata Ayib and Zure are among the common dairy products produced and consumed in the study areas. In general, the consumption pattern of milk and milk products in the study area is characterized by considerable product diversity (Table 11). All the respondents reported that milk is consumed after processing to various products. However, milk is also consumed in its raw state. Eighty eight and sixty eight percent of the respondents in Kedida and Kachabira woredas, respectively reported that they boil milk before use. Consumption of sour milk is rarely reported in the area because it is used for further processing in order to generate income from sale of products such as butter, spiced butter and Metata Ayib.

Traditional milk processing is a common practice of all smallholder farmers who own lactating cows in the study area as it is else where in the country. Butter is used for cooking, for sale and cosmetic purposes (mainly by the female members of the household) (Table 11). All the respondents reported that buttermilk is used for consumption, cottage cheese production, Metata Ayib production and Zure production in both woredas.

In the study area all the milk produced and consumed is obtained from cows (from both local and crossbred cows) and there was no report of shoat milk utilization in the area due to cultural taboo (Table 11). Milk and milk products have other additional functions in the area besides their nutritional value. They use fresh whole milk to neutralize toxins and butter for hair ointment. This result agrees with the report of Zelalem and Ledin (2001a) [19] in the central highlands of Ethiopia. Farmers in the study area reported that Metataa Ayib is used to cure malaria and stomach upset. The medicinal value of Metata Ayib needs further investigation.

Table 11. Dairy products utilization patterns in the study area.

\begin{tabular}{lll}
\hline \multirow{2}{*}{ Descriptions } & Kedida & Kachabira \\
\cline { 2 - 3 } & Respondents (\%) & Respondents (\%) \\
\hline Boiling of milk & 88 & 68 \\
Consumption of dairy products & & 19.8 \\
Raw milk consumption & 25.44 & 5.94 \\
Sour milk consumption & 8.77 & 74.26 \\
Processed dairy products consumption & 65.79 & 24.6 \\
Uses of dairy products & & 45.4 \\
Butter used for food & 27.27 & 30 \\
Butter used for sale & 38.79 & 100 \\
Butter used as hair ointment & 33.94 & 100 \\
Buttermilk used for consumption & 100 & 100 \\
Buttermilk used for Ayib production & 100 & 100 \\
Buttermilk used for Metata Ayib production & 100 & Nil \\
Buttermilk used for Zure production & Nil & \\
Consumption of shoat milk & & \\
\hline
\end{tabular}

$\mathrm{N}=$ number of respondents ( 75 respondents from each woreda).

Among family members, children (babies of less than one year of age) have the privilege to drink fresh whole milk. Second, third, fourth and fifth priority for fresh whole milk consumption are given to husband, guests and sick persons, wife and equal chance to wife and husband, respectively in the study areas (Table 12). This result is a bit contradictory to the report of Alganesh (2002) and Lemma (2004) [4, 20] who reported that husband has better access to fresh whole milk consumption and is given the first priority among the family members in the Oromia region.
Table 12. Priority for fresh whole milk consumption among family members in the study area (weighted average scores).

\begin{tabular}{ll}
\hline Family members & Ranks \\
\hline Children & $1^{\text {st }}(4.2)$ \\
Husband & $2^{\text {nd }}(3.74)$ \\
Guests and sick persons & $3^{\text {rd }}(2.88)$ \\
Wife & $4^{\text {th }}(2.73)$ \\
Wife and husband* & $5^{\text {th }}(1.27)$ \\
\hline
\end{tabular}

Total number of respondents $=150 ; *=$ equal chance to husband and wife. 
The overall rank for consumption of different milk and milk products in the study area is shown in Table 13. Even though all the dairy products are consumed in the study areas, their relative level of consumption varied from household to household depending on the wealth status and the number of lactating cows owned by a household at a time. The respondents ranked cottage cheese, Metata Ayib, ghee and sour milk as their first, second, third and fourth preferences, respectively (Table 13). Zure was ranked as their $5^{\text {th }}$ priority but the respondents claim that this product is the most nutritious of all. The reason for the least preference of Zure is because it is prepared from fresh whole milk and Ergo which are used for further processing. In the majority of the households, Zure consumption is considered as a refreshment and prepared occasionally especially when there is surplus milk production in the household.

Table 13. Reported priority for consumption of various dairy products in the study area (weighted average scores).

\begin{tabular}{ll}
\hline Product & Ranks \\
\hline Cottage cheese & $1^{\text {st }}(6.59)$ \\
Metata Ayib & $2^{\text {nd }}(6.12)$ \\
Ghee & $3^{\text {rd }}(5.86)$ \\
Sour milk & $4^{\text {th }}(4.93)$ \\
Zure & $5^{\text {th }}(3.15)$ \\
Buttermilk & $6^{\text {th }}(2.88)$ \\
Fresh whole milk & $7^{\text {th }}(2.59)$ \\
Whey & $8^{\text {th }}(1.97)$ \\
\hline
\end{tabular}

Total number of respondents $=150$.

Fresh whole milk ranked as their $7^{\text {th }}$ preference as it is accumulated over a few days and fermented naturally as the first step in processing. Whey ranked as last priority by farmers in the study area. According to the response of the framers, their preference is to consume processed milk products because processed products diversify their diets and generate income. In this study, it was impossible to estimate the amount of milk and milk products consumed by a household at a time because the respondents found it difficult to estimate. The high demand for processed dairy products in the area suggests that there is a bright prospect for expanding and improving milk processing in the area.

\subsection{Composition and Microbial Quality of Milk Produced in the Study Area}

\subsubsection{Chemical Composition of Milk}

The overall mean fat, protein, total solids, ash and solids-notfat (SNF) contents of local cows' milk produced in the study area were $4.71,3.25,13.47,0.73$ and 8.78 percent, respectively (Table 14). Whereas the overall mean fat, protein, total solids, ash and SNF contents of crossbred cows' milk were 4.14, 3.45, $13.15,0.70$ and 8.96 percent, respectively (Table 14). Total solids, ash and SNF percentage of the milk did not vary between sites and between farm groups (milk samples obtained from local cows and crossbred cows). Whereas, fat and protein percentages were significantly different $(\mathrm{P}<0.001)$ between farm groups. The variation in the fat and protein percentage across farm groups may be attributed to the breed difference between the cows used, difference in feeds and feeding practices, stage of lactation and parity.

The overall mean fat percentage of local cows' milk obtained in the present study is less than the fat percent of 5.6 reported for Zebu cows' milk [4]. The fat content of whole milk collected from smallholder framers in eastern Wollega was 6.05 percent [20]. On the other hand, the overall mean percent fat of 4.14 for milk of crossbred cows obtained in this study is lower than the value 5.9 percent reported for Borana $\mathrm{x}$ Friesian and Borana $\mathrm{x}$ Jersey crossesbred at Holetta [22]. The variation in fat percentage observed in the present study may probably be due to variation in stage of lactation, feeding regime and pari.

Table 14. Least squares means ( $\pm S E)$ of the chemical components of milk produced in the study area.

\begin{tabular}{|c|c|c|c|c|c|}
\hline Variables & Fat $(\%)$ & Protein $(\%)$ & Total solids (\%) & $\operatorname{Ash}(\%)$ & SNF (\%) \\
\hline Farm groups (BDZ) & $* * *$ & $* * *$ & $\mathrm{NS}$ & NS & NS \\
\hline Local $(\mathrm{N}=21)$ & $4.66^{\mathrm{a}} \pm 0.16$ & $3.25^{\mathrm{b}} \pm 0.03$ & $13.39 \pm 0.2$ & $0.72 \pm 0.01$ & $8.77 \pm 0.11$ \\
\hline Crossbred $(\mathrm{N}=8)$ & $4.1^{\mathrm{b}} \pm 0.14$ & $3.45^{\mathrm{a}} \pm 0.05$ & $12.98 \pm 0.18$ & $0.69 \pm 0.01$ & $8.89 \pm 0.16$ \\
\hline Farm groups (Kachabira) & $* * *$ & $* * *$ & NS & NS & NS \\
\hline Local $(\mathrm{N}=24)$ & $4.75^{\mathrm{a}} \pm 0.15$ & $3.26^{\mathrm{b}} \pm 0.03$ & $13.55 \pm 0.19$ & $0.74 \pm 0.12$ & $8.79 \pm 0.13$ \\
\hline Crossbred $(\mathrm{N}=21)$ & $4.19^{b} \pm 0.14$ & $3.46^{\mathrm{a}} \pm 0.04$ & $13.3 \pm 0.17$ & $0.71 \pm 0.01$ & $9.03 \pm 0.10$ \\
\hline Overall mean of local cows' milk $(\mathrm{N}=45)$ & $4.71 \pm 0.11$ & $3.25 \pm 0.02$ & $13.47 \pm 0.14$ & $0.73 \pm 0.01$ & $8.78 \pm 0.08$ \\
\hline
\end{tabular}

$\mathrm{BDZ}=$ Kedida; $\mathrm{SNF}=$ solids-not-fat; $\mathrm{N}=$ number of observations; Means in a group with in column followed by different letters as superscripts are significantly different; ns=not significant; $* * *=\mathrm{P}<0.001$.

The overall mean protein content of for local cows' milk obtained in the current study is higher than the protein content of 3.1 percent reported for Zebu cows' milk [4]. Similarly, Zelalm and Ledin (2001b) [23] reported an overall mean protein content of 3.1 percent for whole milk in the central highlands of Ethiopia. The overall mean protein content of milk of crossbred cows observed in the current study is lower than the result of Zinash et al. (1988) [24] who reported a mean value of 3.66 percent for Horro $x$ Friesian crosses. Rehrahie and Yohannes (2000) [23] also reported a higher protein percentage of 5.61 for Borana $\mathrm{x}$ Friesian and Borana $\mathrm{x}$ Jersey crosses bred at Holetta. However, it is comparable with 3.5 percent protein content reported for milk of Arsi x Friesian crosses around Asela [25].

The average total solids, ash and SNF content of milk samples collected from both local and crossbred cows in Kedida and Kachabira woredas (Table 15) are comparable with the values reported by other workers. Alganesh (2002) 
[20] reported an overall mean total solids, ash and SNF content of $14.31,0.70$ and 8.22 percent, respectively for local cows' milk in eastern Wollega. Taye (1998) [25] reported a value of 14.8, 0.7 and 8 percent for total solids, ash and SNF content of crossbred cows' milk, respectively around Asela.

Table 15. Least squares means $( \pm S E)$ of the chemical components of milk obtained from individual farmers and dairy cooperatives in Kedida woreda.

\begin{tabular}{|c|c|c|c|c|c|}
\hline Variables & Fat $(\%)$ & Protein (\%) & TS (\%) & $\operatorname{Ash}(\%)$ & SNF (\%) \\
\hline Farm groups & NS & NS & NS & NS & NS \\
\hline Individual farmers $(\mathrm{N}=39)$ & $4.40 \pm 0.16$ & $3.34 \pm 0.03$ & $13.20 \pm 0.14$ & $0.71 \pm 0.01$ & $8.83 \pm 0.08$ \\
\hline Cooperatives $(\mathrm{N}=6)$ & $4.23 \pm 0.17$ & $3.46 \pm 0.05$ & $13.37 \pm 0.35$ & $0.70 \pm 0.01$ & $9.14 \pm 0.19$ \\
\hline
\end{tabular}

$\mathrm{TS}=$ Total solids; $\mathrm{SNF}=$ solids-not-fat; $\mathrm{N}=$ number of observations, $\mathrm{NS}=$ not significant $(\mathrm{P}>0.05)$.

Table 16 shows the least square means and standard error of the milk samples collected from individual farmers and dairy cooperatives in Kedida woreda. None of the variables analyzed in the current study showed significant difference between the milk samples collected from individual farmers and dairy cooperatives (Table 16). The absence of variation between the factors considered might have been attributed to the fact that the dairy cooperatives collect milk of local cows as well as crossbred cows.

\subsubsection{Microbiological Quality of Milk}

Table 17 shows the microbial counts and acidity of cows' milk produced in the study area. The overall mean total bacterial count of cows' milk produced in the study area was
7.6 $\log _{10} \mathrm{cfu} / \mathrm{ml}$. The total bacterial count obtained in this study is generally high as compared to the acceptable level of $1 \times 10^{5}$ bacteria per ml of raw milk [4]. Fekadu (1994) [24] reported that the minimum and maximum total bacterial count of raw cows' milk produced in southern region to be 6 to $8.8 \log _{10} \mathrm{cfu} / \mathrm{ml}$. Similarly, Alganesh (2002) [20] reported total bacterial count of cows' milk produced in Bila Sayo and Guto Wayu districts of eastern Wollega to be $7.4 \times 10^{7}$ and $2.0 \times 10^{7} \mathrm{cfu} / \mathrm{ml}$, respectively. In general, lack of knowledge about clean milk production and use of unclean milking equipment would be some of the factors which contributed to the poor hygienic quality of milk produced in the study area.

Table 16. Least squares means $( \pm S E)$ of microbial counts $\left(\log _{10} c f u / m l\right)$ and acidity of milk produced in the study area.

\begin{tabular}{llll}
\hline Variables & Total bacterial count $\left(\log _{\mathbf{1 0}} \mathbf{c f u} / \mathbf{m l}\right)$ & Coliform count $\left(\log _{\mathbf{1 0}} \mathbf{c f u} / \mathbf{m l}\right)$ & Acidity $(\% \mathbf{l a c t i c}$ acid) \\
\hline Overall mean $(\mathrm{N}=84)$ & $7.58 \pm 0.09$ & $4.49 \pm 0.11$ & $0.23 \pm 0.01$ \\
Location & $\mathrm{ns}$ & $\mathrm{Ns}$ & $\mathrm{Ns}$ \\
Kedida $(\mathrm{N}=39)$ & $7.61 \pm 0.12$ & $4.41 \pm 0.16$ & $0.22 \pm 0.01$ \\
Kachabira $(\mathrm{N}=45)$ & $7.56 \pm 0.13$ & $4.55 \pm 0.15$ & $0.23 \pm 0.01$ \\
Farm groups & $\mathrm{ns}$ & $\mathrm{Ns}$ & $\mathrm{Ns}$ \\
Local cows' milk $(\mathrm{N}=45)$ & $7.70 \pm 0.13$ & $4.52 \pm 0.15$ & $0.23 \pm 0.01$ \\
Crossbred cows' milk $(\mathrm{N}=39)$ & $7.47 \pm 0.11$ & $4.45 \pm 0.15$ & $0.22 \pm 0.01$ \\
\hline
\end{tabular}

$\mathrm{N}=$ number of observations; $\mathrm{ns}=$ not significant $(\mathrm{P}>0.05)$; $\mathrm{cfu}=$ colony-forming units.

The overall mean coliform count of milk produced in the area was $4.49 \log _{10} \mathrm{cfu} / \mathrm{ml}$ (Table 17). The coliform count obtained in the current study is greater than that reported by Fekadu (1994) [24] who found coliform counts of 3.8, 4.0 and $3.8 \log _{10} \mathrm{cfu} / \mathrm{ml}$ for cows' milk produced in Aneno, Gulgula and Dongora districts of southern region, respectively. On the other hand, Zelalem and Bernard (2006) [19] obtained higher coliform count of $6.57 \log _{10} \mathrm{cfu} / \mathrm{ml}$ for cows' milk collected from different producers in the central highland of Ethiopia. The higher coliform count observed in this study may be due to the initial contamination of the milk samples either from the cows, the milkers, milk containers and the milking environment. Thus, extension services and training of farmers in improved milk handling practices are required to improve the raw milk quality in the study area.

The overall mean titratable acidity of cows' milk produced in the study area was 0.23 percent (Table 17). This figure is lower than the finding of Alganesh (2000) [20] who reported an average acidity of 0.28 and 0.31 percent for raw cows' milk produced in Bila Sayo andd Guto Wayu districts of eastern Wollega, respectively. On the other hand, Taye (1998) [25] reported a much higher value $(0.38 \%)$ of titratable acidity for milk produced from crossbred cows around Asela. In general, the high percent lactic acid of milk observed in the present study implies that the manner in which the milk was handled was poor reflecting the substandard hygienic conditions during production and handling of milk in the area.

Table 17. Least squares means ( \pm SE) of microbial counts $\left(\log _{10}\right.$ cfu/ml) and acidity of milk obtained from individual farmers and dairy cooperatives in Kedida woreda.

\begin{tabular}{|c|c|c|c|}
\hline Variables & Total bacterial count $\left(\log _{10} \mathrm{cfu} / \mathrm{ml}\right)$ & Coliform count $\left(\log _{10} \mathrm{cfu} / \mathrm{ml}\right)$ & Acidity (\%lactic acid) \\
\hline Farm groups & NS & NS & $*$ \\
\hline Individual farmers $(\mathrm{N}=39)$ & $7.61 \pm 0.12$ & $4.41 \pm 0.16$ & $0.23^{\mathrm{b}} \pm 0.01$ \\
\hline Cooperatives $(\mathrm{N}=6)$ & $8.12 \pm 0.25$ & $4.94 \pm 0.23$ & $0.28^{\mathrm{a}} \pm 0.01$ \\
\hline
\end{tabular}

Means with different superscript letters in column are significantly different, $*=\mathrm{P}<0.05$; ns $=$ not significant; $\mathrm{N}=$ number of observations; $\mathrm{TBC}=$ total bacterial count; $\mathrm{CC}=$ coliform count; $\mathrm{cfu}=$ colony-forming units. 
The least squares means and standard error of the milk samples collected from individual farmers and dairy cooperatives in Kedida woreda are presented in Table 18. Total bacterial count of milk obtained from individual farmers did not differ significantly from milk collected from the dairy cooperatives. The highest TBC was recorded for milk samples obtained from cooperatives. The highest TBC observed in milk samples collected from the cooperatives might have been due to the time spent by the different farmers while delivering milk to the cooperatives and the poor receiving environment at the dairy cooperatives. Bekele and Bayileyegn (2000) [26] reported a mean total bacterial count of $1.3 \times 10^{7} \mathrm{cfu} / \mathrm{ml}$ for raw cows' milk obtained at milk collection centers in and around Addis Ababa city.

Although no significant difference in $\mathrm{CC}$ was observed between milk samples obtained from individual farmers and the dairy cooperatives; milk samples collected from the dairy cooperatives had higher $\mathrm{CC}$ than milk samples collected from individual farmers.

Milk samples collected from the dairy cooperatives had higher acidity $(p<0.05)$ than milk samples obtained from individual farmers (Table 18). The increased acidity in the milk collected from the dairy cooperatives might be attributed to proliferation of microorganisms during delivery of milk by farmers and further contamination at the dairy cooperatives. The titratable acidity of milk obtained from dairy cooperatives in Kedida woreda is lower than the value reported by Taye (1998) [25], which was 0.50 percent for milk samples collected from cooperative farms around Asela. However, the titratable acidity of milk collected from the dairy cooperatives in the current study is in agreement with 0.27 percent reported by Zelalem and Bernard (2006) [19] for milk samples collected at dairy product shops in the central highlands of Ethiopia.

In general, the microbiological quality of milk obtained from the dairy cooperatives is poor as compared to milk samples obtained from individual farmers. Thus, this calls the need for stringent measures to improve the hygienic quality of milk at the dairy cooperatives.

Clot-on-boiling test: The predicted probability and standard error of clot-on-boiling test for cow milk samples collected in the study area are presented in Table 19. This test showed that 23 percent of the milk samples tested are likely to clot- on- boiling. Alganesh (2002) [20] reported an overall mean value of 21 percent for cow milk samples collected from smallholder farmers in eastern Wollega of Oromia region. This test measures the same characteristics as the alcohol test but is somewhat more lenient than alcohol test [4].

Alcohol test: Table 19 shows the predicted probability and standard error of alcohol test for cow milk samples collected in the study areas. The overall mean value shows that 51 percent of the milk samples tested are likely to clot by the alcohol test. The report of Alganesh (2002) [20] indicated that 58 percent of cow milk samples collected from smallholder farmers in eastern Wollega of Oromia region is likely to clot by alcohol test. These observations support the view that the alcohol test is more sensitive than the clot-onboiling test as reported by O'Connor (1994) [4].

Table 18. Predicted probabilities ( \pm SE) for clot-on-boiling and alcohol tests of cows milk produced in the study area.

\begin{tabular}{lll}
\hline Variables & Clot-on-boiling test & Alcohol test \\
\hline Overall mean $(\mathrm{N}=84)$ & $0.23 \pm 0.12$ & $0.51 \pm 0.11$ \\
Location & & \\
Kedida $(\mathrm{N}=39)$ & $0.26 \pm 0.12$ & $0.50 \pm 0.10$ \\
Kachabira $(\mathrm{N}=45)$ & $0.23 \pm 0.13$ & $0.54 \pm 0.11$ \\
Farm groups & & \\
Local cows milk $(\mathrm{N}=45)$ & $0.27 \pm 0.13$ & $0.55 \pm 0.12$ \\
Crossbred cows milk $(\mathrm{N}=39)$ & $0.23 \pm 0.09$ & $0.49 \pm 0.10$ \\
\hline
\end{tabular}

$\mathrm{N}=$ number of observations.

The predicted probabilities and standard error of clot-onboiling and alcohol test of milk samples collected from individual farmers and dairy cooperatives in Kedida woreda are presented in Table 19. The present study showed that more of the milk samples collected from the dairy cooperatives is likely to clot by both tests as compared to the milk samples collected from individual farmers (Table 19). This result is in agreement with the higher percent of lactic acid observed in the milk samples collected from the dairy cooperatives (Table 19).

Table 19. Predicted probabilities ( \pm SE) for clot- on- boiling and alcohol tests of milk obtained from individual farmers and dairy cooperatives in Kedida woreda.

\begin{tabular}{lll}
\hline Variables & Clot-on-boiling test & Alcohol test \\
\hline Farm groups & & \\
Individual farmers $(\mathrm{N}=39)$ & $0.26 \pm 0.12$ & $0.50 \pm 0.10$ \\
Cooperatives $(\mathrm{N}=6)$ & $0.57 \pm 0.15$ & $0.78 \pm 0.2$ \\
\hline
\end{tabular}

$\mathrm{N}=$ number of observations.

\section{Summary and Conclusions}

\subsection{Summary}

The major cattle breeds kept by farmers in the study area are local Zebu animals belonging to Fogera breed, unidentified indigenous animals and Fogera-Friesian crossbreds. Draught power, milk production, meat production, income generation, manure production and threshing cereal grains are found to be the most important functions of cattle in the area. The major sources of feed for cattle in the study area were natural pasture (grazing), hay, crop residues, crop aftermath and non-conventional feedstuffs (Attela the residue of the traditional beverage Tella and Brinti the residue of Arekie). The area is characterized by recurrent feed shortage. Improved forage and concentrate supplementation is practiced by few respondents. Nonconventional feedstuffs are used as major feed resource for cattle in the study area. Farmers believe that Brinti increases milk yield of lactating cows and thus farmers in the study area use Brinti (the residue of the traditional beverage Arekie) as supplement like concentrates especially for 


\section{lactating cows.}

The average age at first calving (AFC) of the indigenous cows was 4.76 years whereas the average AFC of crossbred cows was 3.05 years. Milk yield of local cows per day was on the average 2.0, 1.2 and 0.6 liters for the first, second and third lactations, respectively with an overall average of 1.2 liters per cow per day. The average daily milk yield of crossbred cows was 7.3, 5.5 and 3.5 liters for the first, second and third lactations, respectively with an overall average of 5.2 liters per cow per day. The overall average lactation length of local and crossbred cows in the study area was 9.8 and 10.1 months, respectively.

Mastitis, trypanosomiasis, anthrax, dermatophilosis, fascioliasis and bloat were the most prevalent diseases in the area. Farmers indicated that anthrax was the most severe disease causing high mortality. According to the respondents, dermatophilosis is the most severe disease that attacks mainly crossbred animals especially when the blood level is greater than 50 percent.

Cows are hand milked and calves are allowed to suckle their dams prior to as well as after milking. Milking of cows in the absence of their calves is also practiced. Even though, all the respondents reported that they wash hands and vessels before milking cows, the sanitary measures taken at different stages in the dairy production chain were generally unsatisfactory in the study area.

Ensira is the major container used for milking and storing dairy products in the study area. The Ensira used for different purposes differ in size. The small size Ensira used for milking is called Shatte while the medium size Bosso used for milk storage is called Zalle and the larger size Ensira used for churning is called Bosso. Plastic containers are also used for milking in the study area. With regard to churning, the majority of the respondents $(98.7 \%)$ in Kedida woreda use Ensira churn while 76.32 percent in Kachabira woreda use clay pot churn, respectively. In general, Ensira, clay pot and plastic containers are used in different proportions for the storage of various milk products produced in the study area.

Ocimum hardiense is the most common plant species used to clean vessels that are used to store milk and milk products followed by yesetkest and nachakitele. Terminalia brownie and Acacia spp. are the most frequently used plant species for smoking milk vessels in the study area. Zewogdem and Tegi are also used for smoking the vessels used to store milk and milk products.

Fresh whole milk, sour milk, butter, buttermilk, traditional cottage type cheese, whey, Metata Ayib and Zure are the major dairy products produced and consumed in the study area with varying degree of consumption pattern. Consumption of fresh whole milk and sour milk is rarely reported in the area because they are used for further processing to various dairy products such as butter, spiced butter and Metata Ayib.

Zure and Metata Ayib are the peculiar traditional dairy products produced in the study area. The raw materials used for Zure making are whole fresh milk, buttermilk, cottage cheese, sour milk and whey. Whereas the raw material used for production of Metata Ayib is buttermilk. The farmers reported that before consumption, the Metata Ayib is thoroughly mixed either with ghee, fresh whole milk or warm water depending on the availability of ghee or fresh whole milk. The reported shelf life of sour milk, cottage cheese, Metata Ayib, butter, spiced butter and ghee were found to be 4.1 days, 2.9 days, 2.8 years, 13.7 days, 11.4 months, and 19.2 months, respectively.

Farmers use the informal marketing system to sell their milk and milk products to neighbours or the local markets. The farmers in Kedida woreda also sale their dairy products through farmers milk marketing channel. The dairy products sold in the study areas are fresh whole milk, butter, spiced butter and Metata Ayib. However, 77.3 and 93.3 percent of the respondents in Kedida and Kachabira woredas, respectively reported problem of marketing of dairy products in the area.

The major constraints to milk production in the area are feed shortage, animal diseases, low milk yield of local cows, inadequate artificial insemination services, lack of milk collection centers and shortage of labour. Whereas the major constraints to milk processing in the study area are: lack of milk collection centers/ lack of market, low milk yield of local cows, poor quality milk products and long churning time.

In the present study, two dairy cooperatives were identified in Kedida woreda; two in Adelo rural kebele and these cooperatives were established with the objectives of facilitating dairy marketing in the area. However, currently there is no dairy cooperative in Kachabira woreda. Both cooperatives collect milk from members as well as nonmembers at a fixed price from both local as well as crossbred cows' milk. Lack of market access, low product price, less demand for processed dairy products such as cottage cheese, lack of cooling facilities coupled with lack of electric power supply and frequent breakage of cream separator are the major constraints encountered by the dairy cooperatives in their order of importance.

The overall mean fat, protein, total solids, ash and solidsnot-fat (SNF) contents of local cows' milk produced in the study area were $4.71,3.25,13.47,0.73$ and 8.78 percent, respectively. Whereas the overall mean fat, protein, total solids, ash and SNF contents of crossbred cows' milk were $4.14,3.45,13.15,0.70$ and 8.96 percent, respectively.

The overall mean total bacterial count, coliform count and percent lactic acid of milk produced in the study area were $7.58 \pm 0.09 \quad \log _{10} \mathrm{cfu} / \mathrm{ml}, \quad 4.49 \pm 0.11 \quad \log _{10} \quad \mathrm{cfu} / \mathrm{ml}$ and $0.23 \% \pm 0.01$, respectively. The overall mean of the predicted probabilities of clot-on-boiling and alcohol tests were $0.23 \pm 0.12$ and $0.51 \pm 0.11$, respectively. The present study showed that the quality of milk produced in the study area was poor. The milk samples collected from dairy cooperatives are inferior in quality as compared to the milk samples collected from individual farmers in Kedida woreda.

\subsection{Conclusions}

1. Some of the farmers had improved forage crops such as 
Napier grass and sesbania, and they showed an interest to participate in dairy production especially to own crossbred cows. Therefore, introduction of good quality adapted forages into the existing production system is crucial to tackle the problem of feed shortage in the area.

2. Community livestock health education and periodical health treatment of animals (vaccination) against economically important diseases must be promoted to improve livestock health in the area.

3. The demand by farmers to own crossbred cows is very high. Therefore, increasing the production of crossbred heifers in the existing ranch and increasing efficiency of AI services in the area are possible alternatives to meet the need of the farmers. Furthermore, maintenance of the blood levels of the crossbred cows around $50 \%$ of exotic inheritance deserves immediate attention.

4. Marketing problem is one of the major bottlenecks for the development the dairy sector in the study area. Therefore, along increased milk production, improvement of the marketing system in the area needs due attention. Group approaches like farmers' milk marketing group, which renders avenue for regular dispatch of milk is an important step forward and therefore should be encouraged.

5. The dairy co-operatives provide farmers with a continuous milk outlet. So strengthening the existing co-operatives and formation of new co-operatives in Kachabira Woreda will have paramount importance as they are serving as an important market outlet for farmers. Involvement of the government is necessary for this to happen.

6. The present study showed that the quality of milk produced in the study area was poor. This was evident from the high values of total bacterial count (TBC), coliform count (CC) and higher percent of lactic acid in the milk. Hence, adequate sanitary measures should be taken at all stages from production to consumption. These measures include proper handling of the cow, personnel hygiene, hygienic milking and processing equipment, improving milk and milk handling environment among others.

\subsection{Recommendation}

From the present finding, the following research interventions are recommended for future work:

1. In-depth study with more representative samples and close monitoring.

2. The role of non-conventional feedstuffs (such as Brinti and Atella) as major feed source has been observed in the study area. Brinti is reported to be the most important feed source compared to Atella particularly in Kachabira woreda. However, the nutritive value and its role on milk composition are not known. Hence, further studies are needed for better utilization of this feed under farmers' conditions.

3. The effects of plant species identified in this study that are used to smoke milk vessels particularly Terminalia brownie on fermentation of milk deserves further investigation.

4. The traditional processing methods used to make Metata Ayib and Zure need optimization and the properties of Metata Ayib and Zure deserve further and detailed scientific investigation.

5. Different types of spices used to preserve butter and Metata Ayib in the study area. The effect of these preservatives on the quality and shelf life of Metata Ayib and spiced butter, their chemical composition as well as the amount to be used calls for further study.

\section{References}

[1] CSA, 2005. (Central Statistical Authority). Federal Democratic Republic of Ethiopia Agricultural sample survey. Livestock and livestock characteristics bulletin, Volume II. Addis Ababa, Ethiopia.

[2] Getachew Eshete, 2002. An assessment of feed resources, their management and impact on livestock productivity in the Ginchi watershed Area. M. Sc. Thesis. Alemaya University, Alemaya. 172p.

[3] MOA, 1996. (Ministry of Agriculture). Animal and Fishery Resource Main Department. Dairy extension manual. Addis Ababa, Ethiopia. 122p.

[4] O’Connor, C. B., 1994. Rural Dairy Technology. ILRI training manual No. 1. International Livestock Research Institute (ILRI), Addis Ababa, Ethiopia. 133p.

[5] O'Mahony, F. and J. Peters, 1987. Options for smallholder milk processing in sub-Saharan Africa. International Livestock Center for Africa (ILCA). ILCA bulletin 27. Addis Ababa, Ethiopia. pp. 2-17.

[6] Falvey, L. and C. Chantalkhana, 1999. Smallholder Dairying in Tropics. International Livestock Research Institute (ILRI), Nairobi, Kenya. 462p.

[7] FAO, 1990. (Food and Agricultural Organization of the United Nations). The technology of traditional milk processing in tropics. FAO year book. vol. 85. FAO. Rome. Italy. 333p.

[8] ILCA, 1987. (International Livestock Center for Africa). ILCA Research Report Number 16. Addis Ababa, Ethiopia. $45 \mathrm{p}$.

[9] Marth, E. H. (ed.), 1978. Standard Methods for the Examinations of Dairy Products. American Public Health Association, Washington, DC. 416p.

[10] Richardson, G. H., 1985. Standard Methods for the Examination of Dairy Products. 15th ed. American Public Health Association. Washington, D. C. pp. 168-196.

[11] SAS, 2000. SAS Users' guide, Statistical Analysis System (SAS) Institute, Inc, Cary, NC.

[12] Solomon Bogale, 2004. Assessment of livestock production systems and feed resources base in Sinana and Dinsho districts of Bale highlands, southeast Oromia. M. Sc. Thesis. Alemaya University Alemaya. Dire Dawa, Ethiopia. 141p. 
[13] Zelalem Yilma and Bernard Faye, 2006. Handling and microbial load of cow's milk and irgo- fermented milk collected from different shops and producers in central highlands of Ethiopia. Ethiopian Journal of Animal Production. 6 (2)-2006: 67-82.

[14] Alganesh Tola, 2002. Traditional milk and milk products handling practices and raw milk quality in Eastern Wollega. M. Sc. Thesis, Alemaya University. Dire Dawa, Ethiopia. $108 \mathrm{p}$.

[15] Rehrahie Mesfin and Yohannes Gojam, 2000. Effect of supplementing concentrates feeds with different ingredients for local and crossbred cows on major milk constituents. pp. 263-267. In: Proceeding of the 7th Annual Conference of the Ethiopian Society of Animal Production (ESAP). 26-27 May, 1999, Addis Ababa, Ethiopia.

[16] Fekadu Beyene and R. K. Abrahamsen, 1997. Farm made fermented milk cottage type cheese in Southern Ethiopia. Tropical Science, 37: 75-79.

[17] Zewdu Wuletaw, 2004. Indigenous cattle genetic resources, their husbandry practices and breeding objectives in Northwestern Ethiopia. M. Sc. Thesis. Almaya University of Agriculture, DireDawa, Ethiopia. 127p.

[18] Zinash Sileshi, Seyoum Bediye, B. W. Michalak and Kebede Teshome, 1988. Observation on the fat and protein contents of the milk of crossbred and local cows. pp. 124-126. In: Proceeding of the Second National Improvement Conference, 24-26 February, Addis Ababa, Ethiopia.

[19] Taye Tolemariam, 1998. Qualities of cow milk and the effect of lactoperoxidase system on preservation of milk at Arsi, Ethiopia. M. Sc. Thesis, Alemaya University of Agriculture, Dire Dawa, Ethiopia. 62p.

[20] Bekele Godefay and Bayileyegn Molla, 2000. Bacteriological quality of raw cow's milk from four dairy farms and a milk collection center in and around Addis Ababa. Berl. Munch Tierarzti. Wschr. 113: 276-278.
[21] Addissu Bitew, 1999. Evaluation of reproductive and growth performance of Fogera cattle and their F1 Friesian crosses at Metekel Ranch, Ethiopia. M. Sc. Thesis. Alemaya University of Agriculture, Dire Dawa, Ethiopia. 84p.

[22] Ahmed, M. M., S. Ehui and Yemesrach Assefa, 2004. Dairy development in Ethiopia. International Food Policy Institute. Available http://www.ifpri.org/dius/eptd/dp/papers/eptdp123pdf.

[23] Azage Tegegne, Geleto A., P. O. Osuji, Tesfu Kassa and J. Frnaceschini, 1994. Influence of dietary supplementation and partial sucking on body weight, lacation and reproduction performance of primiparous Boran (Bos indicus) cows in Ethiopia. Journal of Agriculture Science (Cambridge) 123 (2): 267-273.

[24] Azage Tegegne, Tsehay Redda, Alemu Gebre Wold and K. Hizkias, 2001. Milk recording and herd registration in Ethiopia. pp. 90-104. In: Proceedings of the 8th Annual Conference of the Ethiopian Society of Animal Production (ESAP). 24-26 August, 2000. Addis Ababa, Ethiopia.

[25] Azage Tegene, Workneh Ayalew, Berhanu Gebre Medhin and Salvador Fernandez-Rivera, 2003. Opportunities for improving dairy production in Ethiopia. pp. 107-122. Presented in Ethio-Forum 2002 Resource management for poverty reduction: Approaches and technologies. Ethiopian Social Rehabilitation and Development Fund. Addis Ababa, Ethiopia.

[26] Berhane Mekete and Workneh Ayalew, 2003. Promotion of dairy marketing using farmer's cooperatives: Lessons from India. pp. 81-87. In: Proceedings of 10th Annual Conference of the Ethiopian Society of Animal Production (ESAP). August 22-24, 2002, Addis Ababa, Ethiopia.

[27] Brannang, E. and S. Persson, 1990. A Handbook of Animal Husbandry. Swedish University of Agriculture, Uppsala, Swedien. 127p. 